\title{
Scaffolding: A Promising Approach to Fostering Critical Thinking
}

\author{
Laurie Browne \\ University of Utah \\ Department of Parks, Recreation, and Tourism \\ 250 South 1850 East Room 200 \\ Salt Lake City, UT 84112
}

Phone: (801) 585-1551 • Fax: (801) 581-4930 • E-mail: laurie.browne@hsc.utah.edu

\section{Melissa Hough and Keri Schwab}

University of Utah

melissa.hough@health.utah.edu • keri.schwab@health.utah.edu

\begin{abstract}
Many undergraduate students struggle when asked to engage in critical thinking. One approach we have found useful in fostering critical thinking is scaffolding, a process that involves the use of prompts, supports, and modeling to build a removable structure from which students can learn complex thinking skills. Through the development of these critical thinking skills, students are better able to analyze and formulate recommendations for real world applications. This paper discusses how to incorporate a critical thinking scaffold to guide the design and facilitation of a case-based learning activity in a semester-long commercial recreation management course. Implications for the use of scaffolding in the classroom will also be discussed.
\end{abstract}

KEYWORDS: Critical thinking, scaffolding, case studies 
Teaching students how to think rather than what to think is a primary goal of higher education (Daly, 2001; Kronholm, 1996; Myllykangas \& Foose, 2007), yet many of our undergraduate students struggle when asked to engage in critical thinking. Thinking critically means learners are engaged in "reflective and reasonable thinking that is focused on deciding what to believe or do" (Ennis, $1985 \mathrm{p}$. 44 ), and many college instructors already employ various strategies to engage in this process (e.g. service learning activities, case studies, and journaling). However, the extent to which critical thinking occurs in the college classroom depends largely on students' ability to challenge assumptions, deconstruct information, and reflect on personal beliefs (Brookfield, 1987). In our experiences teaching in higher education, many undergraduate students lack these skills, which may be problematic as they begin to engage in real world contexts. To better prepare our students to be effective leaders in the field, today's learners must be taught how to think critically.

\section{Scaffolding}

One approach we have found useful in fostering critical thinking is scaffolding, which, as both a pedagogical technique and a process, provides a structure for critical thinking. The process of scaffolding involves both the construction and systematic deconstruction of a cognitive support structure that accommodates a student's individual needs (Wood, Bruner, \& Ross, 1976). Additionally, the scaffolding technique serves as a tool that assists learners in completing complex tasks that otherwise would be beyond their capabilities (Puntambekar \& Hübscher, 2005).

Integral to scaffolding is the social interaction between the learner and instructor. Together, they develop a mutual understanding of the activity and its goals, thereby sharing ownership of the process. Through this, the instructor provides support and ongoing diagnosis of the learner's abilities by altering the scaffold to accommodate the learner's needs. Instructional techniques such as expert modeling, student-expert collaboration, and on-going assessment are employed to construct the scaffold. Eventually, the instructor removes the scaffold so the learner takes responsibility for his or her own learning (Wood et al., 1976), which, once completed, leaves the learner more capable than before the use of the scaffold (Lepper, Drake, \& O’Donnell-Johnson, 1997).

\section{Application of Scaffolding Techniques}

In an effort to teach critical thinking during a semester-long commercial recreation management course, we designed a scaffolded syllabus that incorporated case-based learning activities. Case studies, as a pedagogical tool, are realistic scenarios that require students to interpret evidence, analyze information, and formulate an argument (Klebba \& Hamilton, 2007). The ability to demonstrate each of these skills requires students to employ critical thinking. Therefore, we implemented a critical thinking scaffold to guide the design and facilitation of these case study analyses. Following the fundamentals of scaffolding, we integrated these elements into the syllabus: shared understanding of the scaffold, expert modeling, ongoing assessment, and deconstruction of the scaffold. 
We established the critical thinking scaffold in the course syllabus by designing case analysis assignments that increased in complexity and value as the semester progressed. The first case analysis consisted of a 5-point in-class discussion structured around concrete questions such as, "Name the primary stakeholders in this organization," "State your recommendation," and "Identify evidence that supports your recommendation." After the activity, students reflected on the processes they used to formulate a recommendation, specifically with regard to the action words "Name," "State," and "Identify." Several students expressed frustration at the constrained nature of this analysis, which in turn generated discussion on the goal of the exercise within the larger scaffold. Finally, the critical thinking scaffold was outlined on a rubric that students used to reflect on the cognitive processes they employed in each case analysis (See Figure 1). The rubric defined each aspect of the case analysis (identify stakeholders, interpret content, evaluate evidence, analyze assumptions, explain main issues, and construct a final recommendation) in terms of the demonstration of critical thinking (no demonstration, some demonstration, demonstrated, and high proficiency).

Once a shared understanding of the scaffold was established, the instructor and students served as expert critical thinking models. This was accomplished in two ways. First, the instructor demonstrated each critical thinking level as outlined in the rubric and asked students to identify aspects of critical thinking as they were observed. Further, expert modeling was employed through peer-to-peer in-class interactions. At midterm, students identified their personal strengths as they related to critical thinking, and from that point forward they were paired during activities to serve as expert models.

In addition to the feedback given by the expert models, students also received on-going assessment from the instructor. Each case analysis served as an indicator of the students' development of critical thinking skills and we used each assignment to provide individualized and specific feedback. For example, one student assessed her own critical thinking as "highly proficient." The instructor met with her and adjusted her case assignments to allow for a less structured analysis while other students maintained a more structured analysis until later in the semester. This individualized assessment process allowed us to adjust and fade the scaffold as students gained critical thinking skills.

Deconstructing, or fading a scaffold, should occur incrementally over time such that each student thinks critically without using prompts or expert modeling. Once removed, a scaffold should leave the learner with new and readily-employed cognitive skills. In our case study class for example, we first asked the students to analyze cases by identifying and naming concrete pieces of information. Subsequent case analyses required students to think a bit more critically about the case by evaluating types and sources of information. After demonstrating their evaluative skills, students were asked to make inferences about information implicit to the case. By the end of the semester, students were not given case assignments per se. Instead, they analyzed cases in an open-ended paper format. Each aspect of the critical thinking scaffold was faded in this way. 


\begin{tabular}{|c|c|c|c|c|}
\hline & $\begin{array}{c}\text { No } \\
\text { Demonstration }\end{array}$ & $\begin{array}{c}\text { Some } \\
\text { Demonstration }\end{array}$ & Demonstrated & $\begin{array}{c}\text { High } \\
\text { Proficiency }\end{array}$ \\
\hline $\begin{array}{c}\text { Identify } \\
\text { Stakeholders }\end{array}$ & $\begin{array}{l}\text { Fails to identify all } \\
\text { key stakeholders as } \\
\text { they are presented in } \\
\text { the case. }\end{array}$ & $\begin{array}{l}\text { Identifies and } \\
\text { explains all key } \\
\text { stakeholders as they } \\
\text { are presented in the } \\
\text { case. }\end{array}$ & $\begin{array}{l}\text { Identifies and de- } \\
\text { scribes all key stake- } \\
\text { holders as they are } \\
\text { presented in the case } \\
\text { as well as additional } \\
\text { stakeholders not ex- } \\
\text { plicitly mentioned, } \\
\text { begins to describe re- } \\
\text { lationships between } \\
\text { stakeholders. }\end{array}$ & $\begin{array}{l}\text { Identifies all } \\
\text { stakeholders } \\
\text { (explicit and second- } \\
\text { ary) and describes } \\
\text { the relationships } \\
\text { between these stake- } \\
\text { holders and issues } \\
\text { embedded in these } \\
\text { relationships. }\end{array}$ \\
\hline $\begin{array}{l}\text { Interprets } \\
\text { Content }\end{array}$ & $\begin{array}{l}\text { Fails to interpret } \\
\text { all key strengths, } \\
\text { weaknesses, oppor- } \\
\text { tunities, and threats } \\
\text { as presented in the } \\
\text { case. }\end{array}$ & $\begin{array}{l}\text { Interprets all key } \\
\text { strengths, weak- } \\
\text { nesses, opportunities, } \\
\text { and threats as pre- } \\
\text { sented in the case. }\end{array}$ & $\begin{array}{l}\text { Interprets all key } \\
\text { strengths, weak- } \\
\text { nesses, opportunities, } \\
\text { and threats as they } \\
\text { are presented in the } \\
\text { case as some that } \\
\text { is implicit to the } \\
\text { situation. }\end{array}$ & $\begin{array}{l}\text { Interprets explicit } \\
\text { and implicit content } \\
\text { as it relates to the } \\
\text { strengths, weak- } \\
\text { nesses, opportunities, } \\
\text { and threats and de- } \\
\text { scribes connections } \\
\text { between all four. }\end{array}$ \\
\hline $\begin{array}{l}\text { Evaluates } \\
\text { Evidence }\end{array}$ & $\begin{array}{l}\text { Fails to identify data } \\
\text { and information that } \\
\text { counts as evidence } \\
\text { and fails to evaluate } \\
\text { its credibility. }\end{array}$ & $\begin{array}{l}\text { Successfully identi- } \\
\text { fies data and infor- } \\
\text { mation that counts } \\
\text { as evidence but fails } \\
\text { to thoroughly evalu- } \\
\text { ate its credibility. }\end{array}$ & $\begin{array}{l}\text { Identifies all } \\
\text { important evidence } \\
\text { and evaluates it be } \\
\text { describing its source, } \\
\text { type, and how it is } \\
\text { useful. }\end{array}$ & $\begin{array}{l}\text { Not only identifies } \\
\text { and evaluates all } \\
\text { important evidence } \\
\text { (by describing } \\
\text { source, type, and } \\
\text { usefulness), but also } \\
\text { provides new data } \\
\text { or information for } \\
\text { consideration. }\end{array}$ \\
\hline $\begin{array}{c}\text { Analyze } \\
\text { Assumptions }\end{array}$ & $\begin{array}{l}\text { Fails to identify and } \\
\text { evaluate any of the } \\
\text { important assump- } \\
\text { tions behind the } \\
\text { claims in the case. }\end{array}$ & $\begin{array}{l}\text { Identifies some of } \\
\text { the most important } \\
\text { assumptions, but } \\
\text { does not evaluate } \\
\text { them for plausibility } \\
\text { or clarity. }\end{array}$ & $\begin{array}{l}\text { Identifies and } \\
\text { evaluates all the im- } \\
\text { portant assumptions, } \\
\text { but not the ones } \\
\text { that are deeper in } \\
\text { the background-the } \\
\text { more abstract ones. }\end{array}$ & $\begin{array}{l}\text { Not only identifies } \\
\text { and evaluates all the } \\
\text { important assump- } \\
\text { tions, but also some } \\
\text { of the more hidden, } \\
\text { more abstract ones } \\
\text { (the ones not stated } \\
\text { explicitly in the } \\
\text { case). }\end{array}$ \\
\hline $\begin{array}{c}\text { Explain } \\
\text { Main Issues }\end{array}$ & $\begin{array}{l}\text { Fails to identify, } \\
\text { summarize, or } \\
\text { explain the main } \\
\text { problem(s). } \\
\text { Represents the } \\
\text { issues inaccurately } \\
\text { or inappropriately. }\end{array}$ & $\begin{array}{l}\text { Identifies main } \\
\text { issues but does not } \\
\text { summarize or explain } \\
\text { them clearly or suf- } \\
\text { ficiently. }\end{array}$ & $\begin{array}{l}\text { Successfully identi- } \\
\text { fies and summarizes } \\
\text { the main issues, but } \\
\text { does not explain } \\
\text { why/how they are } \\
\text { problems or create } \\
\text { questions. }\end{array}$ & $\begin{array}{l}\text { Clearly identifies and } \\
\text { summarizes main is- } \\
\text { sues and successfully } \\
\text { explains why/how } \\
\text { they are problems or } \\
\text { questions, identifies } \\
\text { embedded or implicit } \\
\text { issues, addresses their } \\
\text { relationships to each } \\
\text { other. }\end{array}$ \\
\hline $\begin{array}{c}\text { Construct } \\
\text { Recommendation }\end{array}$ & $\begin{array}{l}\text { Fails to make a } \\
\text { clear and reasonable } \\
\text { recommendation. }\end{array}$ & $\begin{array}{l}\text { Makes a reasonable } \\
\text { recommendation } \\
\text { but does not provide } \\
\text { any support for the } \\
\text { recommendation }\end{array}$ & $\begin{array}{l}\text { Successfully } \\
\text { constructs a } \\
\text { recommendation } \\
\text { and provides clear } \\
\text { support for the rec- } \\
\text { ommendation based } \\
\text { on evidence from } \\
\text { the case. }\end{array}$ & $\begin{array}{l}\text { Successfully } \\
\text { constructs a } \\
\text { recommendation } \\
\text { and provides clear } \\
\text { support for the rec- } \\
\text { ommendation based } \\
\text { on evidence from } \\
\text { within and from } \\
\text { outside of the case. }\end{array}$ \\
\hline
\end{tabular}

Figure1 adapted from Gilman $\mathcal{B}$ Casey (2006) p.1 


\section{Learning Outcomes and Recommendations}

Learning activities designed within a critical thinking scaffold may produce a variety of observable short and long-term outcomes in student learning. In general, students enjoyed the incremental design of the case studies and felt prepared to tackle the less-scaffolded cases as the semester progressed. Another positive outcome was improved classroom discussion. Students felt comfortable sharing opinions because discussions were supported by predictable cues and structures throughout the semester. Several students said they felt better able to contribute verbally in class because discussion norms were so clearly laid out. A negative outcome resulting from the critical thinking scaffold was the anxiety several students felt about grading ambiguity. Because work done on the case studies did not receive a letter grade, students felt unsure of their overall semester grade.

While the student learning outcomes seem mostly positive, instructors seeking to implement a critical thinking scaffold should be prepared to invest ample time and consideration into student assignments, individual needs, and assessments. This process begins by outlining the goals of the class and the skills necessary to meet those goals. Next, instructors should identify the culminating assignments or projects that will demonstrate reaching those goals. To accomplish this task, instructors should dissect the assignments into smaller portions or sub-skills and format them into mini-projects that will allow students to gain skills progressively throughout the semester. In keeping with the fundamental concept of scaffolding, it is important that instructors give students the opportunity to reflect on the scaffold at each incremental stage and to engage in self-, peer-, and instructor-assessment throughout the semester. Finally, instructors should encourage students to engage their newly-developed critical thinking skills while simultaneously giving them individualized feedback as often as possible.

\section{Conclusion}

We believe the long-term outcomes from the critical thinking scaffold are beneficial to student learning. Through the development of critical thinking, students are better able to analyze and formulate recommendations for future real world applications (Ennis, 1985). By gaining this skill through a scaffolded learning environment, students appreciate instructional supports such as expert models, reflection, and assessment in other contexts. Considered collectively, these skills may contribute to students' self-efficacy and academic success in other learning settings.

\section{References}

Brookfield, S. D. (1997, Fall). Assessing critical thinking. New Directions for Adult $\&$ Continuing Education, 75, 17-30.

Daly, W. M. (2001). The development of an alternative method in the assessment of critical thinking as an outcome of nursing education. Joumal of Advanced Nursing, 36(1), 120-130.

Ennis, R. (1985). A logical basis for measuring critical thinking skills. Educational Leadership, 43(2), $44-48$. 
Gilman, R., \& Casey, J. (2006, Spring). Measuring Critical Thinking. Toolkit, 4(4). Retrieved February 14, 2009, from http://www.niu.edu/assessment/Toolkit/vol4_ish4.pdf

Klebba, J. M., \& Hamilton, J. G. (2007). Structured case analysis: Developing critical thinking skills in a marketing case course. Journal of Marketing Education, 29(2), 132-139.

Kronholm, M. (1996). The impact of developmental instruction on reflective judgment. Review of Higher Education, 19(2), 199-225.

Lepper, M. R., Drake, M. F., \& O'Donnell-Johnson, T. (1997). Scaffolding techniques of expert human tutors. In K. Hogan \& M. Pressley, (Eds.), Scaffolding student leaming: Instructional approaches and issues (pp. 108-144). Cambridge, MA: Brookline Books.

Myllykangas, S. A., \& Foose, A. K. (2007). Building critical thinking one article at a time. Schole: A Journal of Leisure Studies 8 Recreation Education, 22, 79-84.

Puntambekar, S., \& Hübscher, R. (2005). Tools for scaffolding students in a complex learning environment: What have we gained and what have we missed. Educational Psychologist, 40(1), $1-12$.

Wood, D., Bruner, J. S., \& Ross, G. (1976). The role of tutoring in problem solving. Joumal of Child Psychology \& Psychiatry \& Allied Disciplines, 17(2), 89-100. 